налення, навчання протягом усього життя [2]. Цьому сприяє участь молоді в роботі студентського наукового гуртка.

\title{
Література:
}

1. Закон України «Про вищу освіту» 2014 (Верховна Рада України). Офіційний сайт Верховної Ради України. <https://zakon.rada.gov.ua/laws/ show/1556-18\#Text> (дата звернення:16 червня 2021 року).

2. Педагогіка та психологія вищої школи: навчальний посібник / Л.Г. Кайдалова, І.С. Сабатовська-Фролкіна, Н.В. Альохіна, Н.В. Шварп. Х.: НФаУ, 2019. - 248 c.

DOI https://doi.org/10.30525/978-9934-26-113-8-40

\section{MORPHOLOGICAL STUDY OF MASTICATORY MUSCLE FIBERS IN HYPOTHYROIDISM}

\author{
Sahan N. T. \\ Candidate of Medical Sciences, \\ Acting Associate Professor at the Department of Pathophysiology \\ Ivano-Frankivsk National Medical University \\ Antymys 0. V. \\ Candidate of Medical Sciences, \\ Associate Professor at the Department of Human Anatomy \\ Ivano-Frankivsk National Medical University \\ Oliynyk R. P. \\ Candidate of Medical Sciences, \\ Assistant Professor at the Dentistry Postgraduate Education \\ Ivano-Frankivsk National Medical University \\ Melnyk Ya. I. \\ 4th year medical student \\ Ivano-Frankivsk National Medical University \\ Ivano-Frankivsk, Ukraine
}

The study of masticatory muscle morphology has been conducted for a long time by many domestic and foreign scientists $[2,4]$. However, there is no clear and unanimous view on the morphology of this muscle in the 
development of pathology of the thyroid gland, in particular in hypothyroidism.

Therefore, the aim of this study was to establish features of morphological changes in the structural organization of the masticatory muscle of rats in experimentally simulated hypothyroidism.

The material for the study was the masticatory muscle of 30 white outbred male rats, which were divided into groups. Group I - intact, which served as a control (did not perform any manipulations) $(\mathrm{n}=15)$; II - experimental with simulated hypothyroidism $(\mathrm{n}=15)$ Animals before and after the experiment were kept in a specially equipped room, well ventilated, well lit, at a temperature of $+200 \mathrm{C}-+220 \mathrm{C}$, humidity does not exceed $50 \%$, without restrictions in drinking Histological staining with hematoxylin and eosin, Hart's fuchsilin, Van Gizon's hematoxylin-basic fuchsin-picric acid, Stidman's alcyanic blue, Mason's trichromic staining, PAS [2], ultramicroscopic, morphometric and statistical methods of research.

In the study of muscle fibers, edematous changes are also observed, which deepened according to the duration of the experiment. In the study of LDH activity there is blurring and deformation of muscle fibers, enlargement and expansion of intermuscular spaces.Significant cellular infiltration is found in the connective tissue of the endo- and perimysium. Diffuse accumulation of glycosaminoglycans and glycoproteins

was observed. The number of muscle fibers with intermediate LDH activity in the masticatory muscle decreased by $21.28 \%$ (compared to normal). The number of muscle fibers with high LDH activity decreased (by 8.97\%). The number of muscle fibers with low LDH activity increased in the masticatory muscle by $56.91 \%$. There is also an increase in the diameter of the cross section of all types of fibers, compared with the norm. Ultramicroscopic - pronounced changes in muscle fibers. Focal loss of transverse striation was observed because isotropic disks (lane I) and anisotropic disks (lane A), Zlines are deformed and disorganized. The nuclei of muscle fibers are enlarged, their nuclear envelope forms deep intussusception. $\mathrm{M}$ \{visually enlarged, have a light matrix and destroyed ridges.

At 21 and, especially 28 days of experimental hypothyroidism, you can see increasing edematous changes in all types of muscle fibers, and especially in muscle fibers with low activity SDG. The cross-sectional diameter of all types of muscle fibers increases.

We also observed ultramicroscopic changes in muscle fibers, which were manifested by loss of transverse striation, destruction of mitochondrial 
structure, expansion of muscle triads and structural components of the Golgi apparatus.

The described changes are caused by a decrease in the level of basal metabolism, slowing down of redox processes and, as a consequence, tissue hypoxia.Under such conditions, the infiltrate accumulates in large quantities in the main substance, as a consequence - there is cell compression and dystrophy [1].

\section{References:}

1. Боднар П. М. Ендокринологія. Вінниця, 2010. 464 с.

2. Багарян Е. А., Лепилин А. В., Коннов В. В., Батусов Н. В. Изменения функции жевательных мышц у пациентов с переломами нижней челюсти. Развитие стоматологической науки и практики: матер. междунар. науч.-практ. конф. (Полтава, 11-12 ноября 2011). Полтава, 2011. С. 61-62.

3. Багрій М. М., Діброва В. А., Попадинець О. Г., Грищук М. I. Методики гістологічних досліджень. Вінниця, 2018. 328 с.

4. Ciavarella D. Influence of vision on masticatory muscles function: surface electromyographic evaluation. Annali di Stomatologia. 2014. № 2. C. 61-65. 